\title{
Becoming Female Head of a Household: By Force or by Choice?
}

\author{
Tanzima Zohra Habib \\ Department of Social Work, University of Rajshahi, Bangladesh \\ Email: shomiswnus@yahoo.com
}

How to cite this paper: Habib, T.Z. (2020) Becoming Female Head of a Household: By Force or by Choice? Open Access Library Journal, 7: e6825.

https://doi.org/10.4236/oalib.1106825

Received: September 16, 2020

Accepted: October 17, 2020

Published: October 20, 2020

Copyright $\odot 2020$ by author(s) and Open Access Library Inc.

This work is licensed under the Creative Commons Attribution International License (CC BY 4.0).

http://creativecommons.org/licenses/by/4.0/ (c) (i) Open Access

\begin{abstract}
This study sets forth to uncover the background stories of the female heads of households i.e., the routes through which they become the heads of the household in Bangladesh context. The study included 22 purposively selected female heads from Rajshahi-a northwest district in Bangladesh. Using a semi-structured interview guide, qualitative in-depth interviewing technique was employed to gather the detailed life story of the women household heads. To generate themes, qualitative thematic analysis technique was used to analyze the interview texts. The findings suggest that the dissolution of marriage, either by the death of husband or divorce or separation, is the main reason for the development of (de jure) female headships irrespective of economic class and place of living. Only in few cases, situations like husband's out-migration, disability and/or inability to earn an income thrust the (de facto) headship on the women. The study indicates that no woman, regardless of their class positions and places of living, take the charge of household headship willingly. As a qualitative study, the findings of the current study could be flawed by lack of generalization. The study offers empirical knowledge about the experiences of the female heads of households which could provide useful insights for the social workers and policy makers to have a better understanding about the diverse needs of female heads in Bangladesh. The route to female headship in Bangladesh is rarely studied. The current study is an attempt to fill up the study gap.
\end{abstract}

\section{Subject Areas}

Demography, Public Policy, Sociology, Women and Gender Studies, Social Work

\section{Keywords}

Routes to Headship, Female Head of Household, Single Parenthood, Bangladesh 


\section{Introduction}

It is often assumed that families, whether nuclear or extended, are headed by men and rely primarily on a male breadwinner for economic support. However there are also many households all round the world that are headed by women. In recent years the number of female-headed households (FHHs) has been growing rapidly across the world, including countries with very different socio-economic backgrounds and cultural traditions. The rise of FHHs is usually explained by socio-economic factors which cause family dissolutions, such as divorce, separation, widowhood, male or female migrations and so on. Although the incidence of female headship is becoming a common feature of most of the countries, and it has an increasing trend, the different contextual facets of female household headships are rarely discussed in the popular social science literature while their patterns and experiences of female headship are likely to be different in different countries and even different in the regions of the same country.

Kabeer asserts that women are becoming more vulnerable as men increasingly abandon their families in the face of poverty [1]. The familial support system is being eroded and female headed households are expanding due to increasing numbers of divorces and desertions as men move away in search of employment [2]. The dissolution of marriage, either by divorce or abandonment or by death of the husband, has disastrous consequences for the family. A large number of widowed, divorced or destitute women, without grown up sons or male family members, become heads of the household and very often find it difficult to maintain the family. In many cases, death of an adult male earning member, who may be a relative other than husband in some households (such as father/brother), may also bring about such a situation of female headship.

Previous studies showed that women who head households are worthy of especial attention because they are triply disadvantaged: they experience the burdens of poverty, gender discrimination and lack of support as heads of households [3]. The female heads of households in Bangladesh also seem to face these triple disadvantages. Absence of male heads leads to increase vulnerability for women and their dependents in FHHs in Bangladesh. Women may also face problems with regard to cultural resources, negotiations with community and the economic market. In Bangladesh, more women than men are falling into the poverty trap under the existing discriminatory socio-cultural norms and practices.

This study sets forth to uncover the background stories of becoming the female head of a household while also taking into account their social class positions and geographical locations of residence. Hence, the objective of the study was to explore the real life experiences of the women who take charge of the family being the head of the household in Bangladesh.

\section{Background of the Study}

Bangladesh is known to be one of the poorest countries in the world and Ban- 
gladeshi women are considered as poorest among the poor [4]. They are not only poor, but also prejudiced by customs and beliefs, and may also face problems with regard to cultural resources, negotiations with community and the economic market. In Bangladesh, more women than men are falling into the poverty trap under the existing discriminatory socio-cultural norms and practices.

FHHs differ considerably with respect to the routes through which they become female heads. Dissolution of marriage either by widowhood or by divorce, separation or abandonment is the major cause of female headship around the world. Studies also suggest that widowhood is the prime cause of female household headship regardless of cultural and ethnic identities in almost all South Asian as well as in other Asian countries [5] [6]. Widowed women constitute the major portion of the female heads in India [7] [8], Bangladesh [4] [9] [10], Malaysia [11], Philippines [12] and South Africa [13]. Divorce and separation are also found to be the causes of female headship in many countries like in Brazil and Jamaica [14] [15]. Besides, studies showed that in India, Sri Lanka and Bangladesh, desertion also leads to female headship along with divorce and separation [4] [8] [16].

Single parenthood and out-of-wedlock birth play an important part in the formation of FHHs in some parts of the world. A study showed that the most common route to female headship in urban Brazil is to never marry, as almost $38 \%$ of FHHs was consisted of never married women and 30\% of them lived with their minor children [14]. In Botswana, a large majority of single women between 20 - 39 years have children, and constitute a major portion of FHHs [17].

In Jamaica, women tend to engage in visiting relationship, which implies neither legal sanction nor co-residency. Due to the poor economic conditions in the region and resultant high rate of unemployment, males often fail to fulfill his role as economic providers. As a result of the economic condition and consensual pattern of living, women tend to form FHHs to secure their welfare and that of their children [15]. Polygamous marriages are common in sub-Saharan Africa, particularly in West Africa, where each co-wife maintains her own household and act as a female head [18].

Absence of a male breadwinner due to unemployment or male migration often leads to female headship. The type of de facto FHHs are found in countries like Botswana, eastern and southern Africa, Mexico, and South-Asian countries like India, Sri Lanka and Bangladesh [5] [9] [10] [17] [19] [20]. In Sri Lanka, researchers also found this specific category of married female heads of household whose husbands still remain in the household but for physical or mental reasons are unable to shoulder the burden of headship [5]. It is often argued that problems of growing landlessness and the disruption of traditional systems of family governance have led to an increase in the number of women who are abandoned and forced to fend for themselves. Further, female labor force participation has been highlighted as one of the major correlates of female household headship [1] 
[9].

Scholars suggest that the routes to female headship should be paid close attention to the analysis of the consequences of the female headship [10]. The routes to female headship may influence the economic and social well-being and experiences of the female heads. The incidence, patterns and natures of female household headship are strongly influenced by demographic antecedents that vary considerably across countries. It was apparent that besides being predominantly quantitative in nature, previous studies mostly depicted the poverty situation among the FHHs. The various routes through the women become the head of the households, particularly in Bangladesh, which is rarely studied. Further, the heterogeneity among the female heads in terms of the routes through they become the household head in relation to their class position and geographic locations of residence, has been a relatively less studied area. The current study is an attempt to fill up the study gap.

\section{Methods}

Study Design and Sites under Study: This study considered qualitative ethnographic method [21] more appropriate in order to obtain the in depth understanding regarding the detailed life situations of the female heads. The study was conducted in both rural and urban communities in a northwest district of Bangladesh, Rajshahi Division. Rajshahi is one of the six administrative regions; and the poorest region in the country. It consists of 16 districts and 128 sub-districts. The total population of Rajshahi is about 35 million and around 29\% of them are below the poverty line [22]. There were two study sites-one rural and another urban. The rural study site was located in Paba, one of the nine sub-districts in Rajshahi District, whereas the urban site was located in Raninagar, one of the wards of the Rajshahi City.

Data for this study comprised with the voices and real life experiences of female heads of households from different economic class i.e., with different income level and from different rural and urban location. The sample for this study was the female heads of households, who were financially responsible for running their family, with minimum age of 21 years, regardless of their marital status. Sample FHHs were taken purposively from different income level and regional contexts like rural villages, and from the city.

Samples: The definition of FHHs that has been used in this study is confined to the households where women are the main bread earners for the family in the presence or absence of their husbands or other adult male members irrespective of their marital status. Purposive sampling method was employed to recruit the participants in this study who were the main breadwinners of the family. Qualitative study is about depth, context and process rather than quantity and the potentiality of purposeful sampling lies in selecting information-rich cases to investigate in-depth [23]. Therefore, the purposive sampling method was used to include in the research a small but heterogeneous and diverse group of female 
heads of households in terms of age, marital status, socio-economic class and rural and urban locations. The sample size of the study was 22 female heads of households. To collect data from the participants, the current study followed in-depth interviewing technique.

Data Analysis: For analyzing the data collected from in-depth interviews, thematic analysis was used, as thematic approach produced an insightful analysis that answers particular research questions. Thematic analysis is a method for identifying, analyzing and reporting patterns or themes within data [24]. For the analysis of the data, all recorded interviews were transcribed in Bangla (the native Language of Bangladesh through which the interview was conducted) and later translated into English. Though this was a laborious process, it provided a firmer grip on the interview data. These verbatim transcripts were the ground for the analysis. After transcribing the data, and going through it carefully, the analysis begins with the searching for meanings and patterns and then the identification of categories or sub-themes, goes to the grouping together into themes, and finally extends to the finding of main themes.

Ethical Issues: The study was conducted in accordance with the operational guidelines and procedures for research with women recommended by the Bangladesh Medical Research Council (BMRC). All the study participants were informed about the purpose and procedures of the study and their oral consent was obtained before the data collection and audio-recording of the interviews. Written consent was waived because there were many illiterate study participants. The respondents were assured about confidentiality of their identity. It was explained to them that they will not be identified or be identifiable in any way, because the data will be anonymous at the time of analysis.

\section{Study Findings}

The qualitative analysis of the interviews with female household heads in the study area reveals two main themes as the basic categories of headship: de jure routes to female headship and de facto routes to female headship. The de jure female heads are the women who are the main bread earners of the household where there is no adult male member present. Desertion by the husband; desertion by the wife, and widowhood was emerged as the sub-themes from the analysis of the interview text data. Whereas, the de facto female heads are those, who are earning the livelihood in the presence of an adult male.

\section{De jure female heads}

It appeared from the findings of the current study that circumstance like dissolution of marriage either by the death of husband or divorce or separation was the main reason for being the head of the household for the female heads irrespective of their economic class or the place of living. No female head was found to be never married single woman in the sample.

\section{Desertion by the husband}

It was revealed that the poor female heads had no option left except for taking 
over the responsibility of the family and becoming the head-main breadwinner as well. This is because no relative either from natal family or from the in laws was interested to shoulder the burden of her family. The narratives of the study participants presented the stories of their abandonment that indeed forced them to take charge of the family.

"18 years ago, I was married with a rickshaw driver. Our family was running with his income and I was a housewife. When I was pregnant, one day my husband did not come home and from that day he never came back... Later, I heard that he went to India and there he got married. I had to move from my rented residence because without my husband's income it was not possible for me to run the family. I came back to my natal house and there I gave birth to a son. But my mother was dependent on my brothers and my brothers were not interested to take my responsibility. There was no way for me to earn my livelihood except begging... Even I started to begin the marketplace with my 18 months old son. Fortunately, one of my rich neighbors lent me some money to start a small business. He also introduced me to a supplier of garment clothes. From that day, I started to sell undergarments from door to door and thus I was able to earn the livelihood and run my family..." (Interview No. 11, a deserted woman).

The interviews of 42 years old female head from an urban area also revealed the similar story-same category-as she expressed:

"After my marriage, the family was running with the income of my husband... When my older daughter was two years old, I was pregnant again and became very sick. But my husband or in-laws did not seek any kind of treatment for me. I was forced to go back to my mother's house and there I got treatment. After some days I gave birth to a son but unfortunately he could not survive. After that incident, my husband never made inquiries about my daughter and me... Later I heard that he got married again. I didn't want to go back to him as one of his wives... Rather I started to work as a maid and earn my own livelihood. My brothers were not interested to take the responsibility of me and my daughter... Even they were unwilling to take care of my mother. So I started my own household with my daughter and my mother" (Interview No. 12, an abandoned woman).

\section{Desertion by the wife}

This sub-theme, under the category-de jure route to female household headship-emerged from a 35-year-old distinct woman-who left her husband due to his irresponsibility towards the family. It could be noted that she was the only woman among the respondents who exposed the courage to leave her husband. She said:

"I stayed with my husband who was a rickshaw driver; he did not give the family expenses regularly... it was really hard to run the family when there 
is no regular income. When I was with my husband, I never knew how much he earned... he never told me... he just gave the money so that I can arrange the food for the day... the next day I have to wait for the daily expenditure... it was so uncertain... someday he did not give anything and I did not know how to run the family... you know, it was too tough to endure this uncertainty... I wanted to get a job so that I can earn by myself... but my husband did not allow me to get a job... besides, if I could get a job there, people would say that why the woman get outside for earning despite having a husband... it is not appreciated, you know... there was regular confrontation between us... finally I decided to leave my husband... I came back to my natal home and found a job... I started to live separately and became the head of the household..." (Interview No. 5, a separated woman).

\section{Widowhood}

However, the story differs according to the economic class of the women heads. The female heads from the higher economic class had options to choose-from being dependent on her natal home to running the family by their own. However, in many cases, they prefer the latter and became the household head. A 35-year old female head with a job in a clerical position in urban area elaborated the background of her being the head of the household:

"when my husband died, I was totally helpless... then my brothers who were financially solvent enough, offered me to stay with them... but I didn't want to be the burden of others... rather I sought a job and decided to run my family with my own earning..." (Interview No. 9, a widow).

Another female head from an upper class household, who was holding a first class position in job, disclosed her story of becoming the female head:

"Before the death of my husband I was staying in a rented floor in my father's flat. When my husband died, my father and brother offered me to merge with them. No doubt it would be easier to maintain the family if I would live with them... but I preferred to live individually in a separate floor with my son. Now I have to maintain my job and all the household chores by myself... however it gives me the feelings of self-worth... I don't want to be a burden of others" (Interview No. 10, a widow).

\section{De Facto Female Heads}

The de facto female head refers to the woman, responsible for the maintenance of household or share such responsibility even when an adult male is present. From the findings of the study, it was found that the female heads became the de facto heads of the households mainly due to the disability or reluctance of their husband to bear the responsibility to run the family, though they were staying in the same households. In the present study, it was found that all the de facto female heads belonged to the poor economic class-there were no 
female head from the higher class who was heading the household despite the presence of her husband. The interviews with a 35-year old female head from an urban poor household visibly revealed this de facto category:

"I got married 15 years ago. My husband was a rickshaw driver and our family was running with his income...12 years ago, when I was pregnant, my husband started to take drug and became addicted... He stopped providing the family expenditure and spent all the money to buy his drug. Since then it was very difficult for me to maintain the family...After the birth of my son, my husband gave the family expenditure for a few days. But soon he started to spend all his income for the drug... Even he had been unable to work because of the effect of taking drug. My brothers or in-laws were not financially sound enough to take the responsibility of my family. In this circumstance, I borrowed some money from my neighbors and started a small business. Since then, my family has been running with my income and I have been the head of my family..." (Interview No. 13, a married woman).

\section{Discussion}

From the findings, it appears that the dissolution of marriage, either by the death of husband or divorce or separation, is the main reason for the development of (de jure) female headships irrespective of economic class and place of living. Only in few cases, situations like husband's out-migration, disability and/or inability to earn an income thrust the (de facto) headship on the women in Bangladesh. The study also indicates that no women, regardless of their class positions and places of living, take the charge of household headship willingly.

In terms of the circumstances leading to female headship, the narratives of the female heads didn't differ much in terms of their place of living i.e., rural or urban area. Widowhood, divorce or separation was the leading cause of the female headship no matter where they live in. The similar pattern was emerged from the interviews with the poor women heads that husband's remarriage had turned the circumstances of the respondents' lives and as a result the latter became the main breadwinners of the newly constituted family regardless of their place of living. This could be possible because of the fact that the Muslim law and the existing norms and values accept polygamy. In Bangladesh, The Muslim Family Laws Ordinance of 1961, which governs marriage and divorce, allows men to have up to four wives, provided each wife is treated equally [25]. However, the specific conditions under which polygamous marriages are allowed in the laws ought to be rarely followed. In a patriarchal society like Bangladesh, the husband has a unilateral right to divorce his wife without even showing grounds, and this could be a reason for the increasing cases of divorce, separation and abandonment.

There are no sanctions against men who do not support their families and the wives generally move back to their natal home with the child (ren). Further, ac- 
ceptance of polygamous marriages in Muslim Family laws thrust women in a more challenging and vulnerable position. Significant proportions of these women emerge as female heads, and often find it difficult to struggle for survival. Even though the Muslim Family Ordinance of 1985 states that a husband should seek his wife's consent before remarrying, the researcher's observation is that, the husbands seldom follow this law. Especially, in poor and lower middle class families, where the wives are mostly uneducated or have a lower level of education, the women are either unaware of this law or they do not have the financial support or courage to take legal action against their husbands for remarrying, without their consent. Therefore, it was sought that women, mainly the poor women, were not able to enjoy the benefit of their legal rights.

A remarkable finding of the current study was that it clearly revealed the dissimilarities between the women heads from poor economic class and the well-off economic class. Though the main route to be the female head was the dissolution of marriage, the situation was different for the women from poor class and the women who belong to the higher economic status. Among the women heads from poor economic class, no one was involved in any kind of economic activities before becoming the head of the household. After the dissolution of marriage, they had to participate in income generation and took the responsibility to run the family. As there was no one from the in laws or from their natal family to take charge of their family, the women had bound to be the head of the household. Therefore, the headship was thrust to them rather being a choice.

On the other hand, it was revealed that the women from higher economic status had the opportunity to choose. Their natal family was willing to bear the family responsibility. However, they select to be the head of the household and run the family all by themselves. This may be because of the awareness of self-dignity they had and the opportunity of having a good job as well. While they had the economic stability, they preferred to be self-reliant. Though there were many hurdles to struggle with, they preferred self-worth than being dependent on others.

\section{Limitations and Policy Implications}

The findings of any qualitative study often have limited scope for generalization because the goal of such research is rather to provide context specific detailed information about human experiences and phenomena of a relatively small sample. Hence, the findings of the current study could be flawed by lack of generalization. However, the rich detail and contextual information regarding the female heads provided in the present study will enrich the existing knowledge regarding FHHs.

The current study offers empirical knowledge about the experiences of the female heads of households from different class positions and locations which could provide useful insights for the social workers and policy makers to have a better understanding about the diverse needs and the support networks of FHHs 
in Bangladesh, and will be useful to identify those FHHs, who are particularly vulnerable. To provide adequate help for the female heads, social work intervention programs can be developed to pay more attention in building their personal resources. The research findings could be useful for social and developmental agencies working for the improvement of women's conditions and will be helpful in developing social interventions for this disadvantaged and marginalized group.

As there is paucity of research in dealing with the female headship issue in Bangladesh, and most of them are predominantly quantitative in nature, the current study is one of the very few studies which employ qualitative approach to capture the detailed life situations of the female heads. It is expected that this study would broaden the potentials of future research directions and expedite the understanding of the emerging needs of the female headed households.

\section{Conclusion}

The qualitative data not only presented the background stories of the respondents, but also depicted their distressing situations during the transitional period particularly for the poor women heads. In Bangladesh, daughters are considered as temporary members of their natal family. Once women are married, they are expected to adjust as best as they can with their husband's families. Except in case of abuse, women who stay married are better off than those whose marriages break down [26]. Conventionally a woman looks for support from her natal family, if her marriage gets into difficulty. But in poor families, if a woman returns to her parental home, she may bring shame and often an economic burden. When the woman's natal family is poor or not able to support her, she has little option to survive. Thus, the respondents, who were abandoned or divorced by their husbands, had to become the head of the family as a way to survive. In a nutshell, a woman in Bangladesh becomes a female head of a household not voluntarily, but due to the adverse situation mostly like dissolution of marriage.

\section{Conflicts of Interest}

The author declares no conflicts of interest regarding the publication of this paper.

\section{References}

[1] Kabeer, N. (1994) Reversed Realities: Gender Hierarchies in Development Thought. Verso, London.

[2] Islam, T. (2007) Microcredit and Poverty Alleviation. Ashgate, Burlington.

[3] Buvinic, M. and Gupta, G.R. (1997) Female-Headed Households and FemaleMaintained Families: Are They Worth Targeting to Reduce Poverty in Developing Countries? Economic Development \& Cultural Change, 45, 259-280. https://doi.org/10.1086/452273

[4] Mannan, M.A. (2000) Female-Headed Households in Rural Bangladesh: Strategies for Well-Being and Survival. Centre for Policy Dialogue, Dhaka.

[5] Ruwanpura, K.N. and Humphries, J. (2004) Mundane Heroines: Conflict, Ethnicity, Gender, and Female Headship in Eastern Sri Lanka. Feminist Economics, 10, 
173-205. https://doi.org/10.1080/1354570042000217766

[6] Momsen, J.A. (1991) Women and Development in the Third World. Routledge, London. https://doi.org/10.4324/9780203329610

[7] Panda. P.K. (1997) Female Headship, Poverty and Child Welfare: A Study of Rural Orissa. Economic and Political Weekly, 32, WS73-WS82. http://www.jstor.org/stable/4406010

[8] Tripathy, T. and Mishra, P. (2005) Female Headed Households Resources and Constraints: A Study on Orissa, India. Asia-Pacific Journal of Rural Development, 15, 77-94. https://doi.org/10.1177/1018529120050106

[9] Islam, M. (1993) Female-Headed Households in Rural Bangladesh: A Survey. In: Mencher, J.P. and Okongwu, A., Eds., Where Did All the Men Go? Female-Headedl Female-Supported Households in Cross-Cultural Perspective, Westview Press, Boulder, 233-242. https://doi.org/10.4324/9780429267550-11

[10] Joshi, S. (2004) Female Household-Headship in Rural Bangladesh: Incidence, Determinants and Impact on Children's Schooling. Center Discussion Paper No. 894. Yale University, New Haven.

[11] Omar, D.B., Ahmad, P. and Sarimin, M. (2005) Urbanization and the Wellbeing of Female Headed Households in Malaysia: The Case Study of Lower Income Single Mothers in Urban Centres. 8th International Conference of the Asian Planning Schools Association, Penang, 11-14 September 2005.

[12] Morada, B.H., Llaneta, M.A., Pangan, T.N. and Pomentil, C.L. (2001) Female-Headed Households in the Philippines. In: The DOLE First Research Conference, The Occupation Safety and Health Center, Quezon City, 5 December 2001.

[13] Posel, D.R. (2001) Who Are the Heads of Households, What Do They Do, and Is the Concept of Headship Useful? An Analysis of Headship in South Africa. Development Southern Africa, 18, 651-670. https://doi.org/10.1080/03768350120097487

[14] Barros, R., Fox, L. and Mendonca, R. (1997) Female-Headed Households, Poverty, and the Welfare of Children in Urban Brazil. Economic Development \& Cultural Change, 45, 231-257. https://doi.org/10.1086/452272

[15] Handa, S. (1996) The Determinants of Female Headship in Jamaica: Results from a Structural Model. Economic Development \& Cultural Change, 44, 793-815. https://doi.org/10.1086/452245

[16] Unisa, S. and Dutta, N. (2005) Female Headship in India: Levels, Differentials and Impact. Paper Presented at the 25th Conference of IUSSP in France.

[17] Kossoudji, S. and Mueller, E. (1983) The Economic and Demographic Status of Female-Headed Households in Rural Botswana. Economic Development \& Cultural Change, 31, 831-859. https://doi.org/10.1086/451360

[18] Desai, S. and Ahmad, S. (1998) Female-Headed Household. In: Nelly, P.S., Ed., Women in the Third World: An Encyclopedia of Contemporary Issues, Garland Pub., New York, 227-235.

[19] Chant, S. (1997) Women-Headed Households: Diversity and Dynamics in the Developing World. Macmillan, Houndmills. https://doi.org/10.1057/9780230378049

[20] Gulati, L. (1993) In the Absence of Their Men: The Impact of Male Migration on Women. Sage Publications, Thousand Oaks.

[21] Creswell, J.W. (2012) Educational Research: Planning, Conducting, and Evaluating Quantitative and Qualitative Research. 4th Edition, Pearson, New York.

[22] World Bank (2013) Bangladesh Poverty Assessment: Assessing a Decade of Progress in Reducing Poverty, 2000-2010 (Bangladesh Development Series Paper No. 31). 
The World Bank Office, Dhaka.

[23] Patton, M.Q. (1990) Qualitative Evaluation and Research Methods, SAGE Publications, Inc., Thousand Oaks.

[24] Braun, V. and Clarke, V. (2006) Using Thematic Analysis in Psychology. Qualitative Research in Psychology, 3, 77-101. https://doi.org/10.1191/1478088706qp063oa

[25] Zaman, H. (1999) Violence against Women in Bangladesh: Issues and Responses. Women's Studies International Forum, 22, 37-48. https://doi.org/10.1016/S0277-5395(98)00093-4

[26] White, S.C. (1992) Arguing with the Crocodile: Gender and Class in Bangladesh. Zed Books, London. 